\title{
Erken Dönem Azerbaycan Maarifçiliğinde Kültürel Kimlik Algısı*
}

\section{Rameş Rzayev $^{* *}$}

öz

Azerbaycan’n siyasi ve felsefi düşünce tarihinde Maarifçilik bir paradigma olarak bazı çelişkilerine ve ikilemlerine rağmen milli tarih literatüründe önemli bir yere sahiptir. 19. yüzyılda Çarlık Rusyası'nın Azerbaycan’a dayatmış olduğu sosyal-kültürel alandaki düzenlemeleri yeni toplum oluşturma bakış açısına uygun gerçekleştirildiği aşikârdır. Maarif̧̧ilik dünya görüşünün temsilcileri olan Abbaskulu Ağa Bakıhanov, Mirza Kâzım Bey ve Mirza Fetali Ahundov'un fikri faaliyetleri bir bakıma yeni bir toplumun yaşam biçimini kurgulama varsayımı üzerine kurulmuş olduğu kanaati bu noktada Avrupamerkezci bakış açısıyla örtüşmektedir. Rusya etkisiyle gerçekleştirilen modernleşme söyleminin Azerbaycan'ın düşünce hayatına, milli-kültürel anlayışına yeni bir nitelik kazandırmakla birlikte neredeyse yaşamın her alanına etki ettiği görülmektedir. Çarlık Rusyası'nın Azerbaycan toplumuna karşı yürüttüğü ayrımcı-yayılmacı politikaları, milli ve kültürel kimlik üzerindeki tahribat girişimleri hegemonya hüviyetinin açık tezahürü olarak bu gibi faaliyetlerle desteklenmekteydi. Modernleşme süreci olarak nitelendirilen değişim çizgisi milli kültür ve kimlik olgusunun merkezi problemini "biz ve öteki" kavramı içine sıkışırması bir bakıma "yeni” kimlik oluşturma anlamına gelmekteydi. Maarif̧̧ilik akımının milli kimlik bilincine ilişkin görüşleri oryantalist bir muhtevada tanımlaması bu gerçeği açığa çıkardı. Rusya’nın etkisiyle var olan dönem entelektüelleri modernleşme söylemine dayanarak ileri sürdükleri görüşler Çarlık hegemonyasının karakterine uygun gelecek nitelikteydi.

\section{Anahtar Kelimeler}

Azerbaycan maarifçiliğii, aydınlanma, ayrımcılık, hegemonya, kültür, kimlik, yayılmacilık.

Geliş Tarihi: 13 Şubat 2018 - Kabul Tarihi: 30 Ocak 2019

Bu makaleyi şu şekilde kaynak gösterebilirsiniz:

Rzayev, Rameş (2020). "Erken Dönem Azerbaycan Maarifçiliğinde Kültürel Kimlik Algısı”. bilig - Türk Dünyası Sosyal Bilimler Dergisi 95: 123-148.

" Doktora Öğrencisi, Sakarya Üniversitesi, Sosyal Bilimler Enstitüsü, Tarih Bölümü - Sakarya/Türkiye ORCID ID: 0000-0001-9699-8116

ramesrza@gmail.com 


\section{Giriş}

18. yüzyıldan itibaren Azerbaycan tarihi karmaşık ve bunalımlı bir döneme sahne olmuştur. Türk asıllı Safevi hanedanının çöküşünü müteakip ülkeyi saran iç savaş, Azerbaycan'ın Kuzey kısmını derinden etkilemiş ve ülke zaman zaman birbiriyle kanlı çatışmalara girebilecek birçok feodal hanlıklara bölünmüştür. Siyasi bölünmüşlügün sosyal-kültürel hayatta meydana getirdiği bir dizi “infial ve belirsizlik” (Nuriyeva 2015: 159) iki farklı eksende cereyan etmiştir. Bu dönem Osmanlı İmparatorluğu’nun askeriidari alanlardaki tenezzülü, Kafkasya ve Azerbaycan'ın Rusya tarafindan işgaline zemin hazırlamıştır. Kısacası, 1805-1812 ve 1826-1828 tarihlerde yürütülen Rusya-İran savaşlarında zafer elden etmiş Rusya, 1813'te imzalanan Gülistan, 1828'de Türkmençay Antlaşmaları ile Azerbaycan'ın Kuzey bölgesini hâkimiyeti altına almıştır (Açıkkaya 2010: 405). Azerbaycan tarihi ve siyasi hayatında meydana gelen bu tahribat, ciddi bir tehlike olarak toplumu siyasi-ekonomik ve sosyal-kültürel düzeyde yeni arayışlara itmekle birlikte onun tarihsel çizgisini de değiştirmiştir.

Ön planda cereyan eden siyasi-askeri hadiseler bölgenin ilhakına yönelik gelişmelerin sadece bir yönünü kapsamaktaydı. Diğer bir yönü ise sömürgeye karşı direncin kırılması istikametinde merkezi yönetim (Çarlık) tarafından uygulamaya konan "medenileştirme ve bilgi” politikasıydı. Bu politik çizgi yeni hegemonik konsept çerçevesinde tesis edildi. Başlangıç evresinde Çarlık Rusyası’nın Azerbaycan'a yönelik politikası "mülkiyet ve sahip olma” olarak tabir edilen sistemin karışımıyla ortaya çıktı. Özellikle Azerbaycan'da mülkiyet hukukunu tanzim eden 6 Aralık 1846 tarihli kanunun muhtevası yeni sömürgeci anlayışın izlerini taşımaktaydı. Süre gelen toplumsal bütünlüğün tahribi mülkiyet elde etme ile anlam kazanmaktaydı. Bu kanun 1841'de ağalardan, beylerden, hanlardan müsadere olunan toprakları geri vermesiyle bağlı olsa da toplumsal katmanları etkileyen bir boyutaydı. Çünkü ilk kez halk ile merkez (Çarlık) arasında bir aracı sınıfın oluşturulmasına yönelik bir adım atıldı. Yani sömürge yönetimi işinde faydalanabilecek ve kendi rejimine tutanak olacak yerli zadegân sınıfını oluşturabilme gayesi bu kapsamda oldukça dikkat çekiciydi (Baykara 1966: 49).

Bu durum, işe yarar potansiyele sahip unsurları hükümetin idaresine dâhil etti. Yani bir bakıma hegemonik güç, sisteme özgü bilgileri sağlayacak 
entelektüellere ve aydınlara olan ihtiyacı karşılamak üzere yeni ideolojik işlevleri devreye soktu. Mülkiyetten sonra ilk olarak "bilinç ya da bilgi' yolu ile kendi dayattığı kimliğe bağlayan mekanizmaları oluşturdu." (Gramsci 1986: 318). Artık emperyalizmin yeni bir cihette ilerlemesi gerektiği fikri belirleyici olmaya başladı. Foucault'nun çözümlemesinde bu gibi durumlar şöyle izah edilmektedir: “...tahakküm ve hegemonya, toplum içi ilişkileri yok etmek ve sınırlandırmak yerine onu en iyi şekilde disipline etmek, örgütlemek ve denetlemek aygıtları kullanılmıştır." (2014: 17).

Mehmetzade'nin (1991: 27) kitabında söz konusu olan durumla ilgili şunları yazmıştı: "Rus işgali sonrası ilim, edebiyat ve sanat ocağı olan Hanlık sarayları yıkıldıktan sonra ve yeni zadegân zümresi gerek donanım, gerekse sorumluluk ve imkân itibariyle çok aşağı düzeyde bulunduğundan, kültür ve fikir hayatı bütünlükle sönüktü." Bu anlamda, toplumsal sorunların çözümüne yönelik yeni tipli kadroların yetiştirilmesi maarif̧̧iliğin başka bir boyutunu ortaya koydu. Çünkü yeni sistem içinde "aydın" kavramı kapsamı alanına girebilmek için Avrupai tarzda öğretim görmüş olmak bir ön koşul olarak belirleyiciydi (Açıkkaya 2010: 406).

Çarlık Rusyası'nın emperyalist politikalarında yeni bir boyut kazanan yayılmacılık çalışmaları, bürokratik mekanizma vasıtasıyla yürütülüyordu (Velihanov 1983: 99). Özellikle kullanılan asimilasyon ve entegrasyon “...politikalarında böl-yönet denklemi” (Hodgson 2017: 263) dikkatli bir şekilde uygulanıyordu. Bilhassa, asimilasyon kapsamında oryantalizm çalışmaları din, dil ve kültürel kimlik gibi alanların titizlikle öğrenilmesi ve tetkik edilmesi, etkinin temel dinamiği olarak öne çıkmaktaydı. Rusya oryantalizm çalışmalarını bu noktadan sonra teoriden pratik alana aktarmaya başladı. Düşünülen her bir tedbir ve girişim Türk-Müslüman toplulukları arasında Ruslaştırmayı yaymak ve milli bilinci imha etmek üzerine planlanmıştı (Can 2017).

Köklü ve etkin tarihi köklere sahip olan Azerbaycan toplumunun kültürel kimliğinden kopuk bir kimlikle tanımlanması düşüncesi Çarlık yönetiminde yaygındı. 19. yüzyılın ilk çeyreğinden itibaren Azerbaycan halkı "Tatar", "Müslüman Tatarları" ya da "Rusya Müslümanları" gibi muğlak kavramlarla tanımlanmaktaydı. Kullandığı dil "Tatarca" isimlendirilmişti. "Tatar" tabiri Rusya Müslümanlarına dair resmi yazışmalar için "Lingua franca" (müşterek lisan) olarak kullanılması zorunluluğu getirilmişti (Zenkovsky 
2000: 12). 1840-1850'li yılları arasında Kafkasya Canişini (Valisi) olarak görev alan Vorontsov'un izlediği kültür politikasında sansürün izin verdiği belirli konular ele alınmaktaydı. Yerel dil, din, folklor ve edebiyat ile ilgili alanların tetkikinden sağlanan bilgiler tam bir tezat teşkil edecek şekilde kullanılmaktaydı (Swietochowski 1988: 26). Daha sonraki dönemlerde toplumsal ögeleri sömürüye en uygun hale getirme projesi uygulanmaya konması için bu bilgilerden faydalanılacaktı.

$\mathrm{Bu}$ çalışmamızda, "kültürel kimlik" olgusu içerisinde Azerbaycan maarifçiliğinin kavramsal tanımından kaynaklanan çelişkileri, ikilemleri ve dönüşümleri ortaya koyarak, "maarifçiliğin" temel problematikasını Foucault'nun "bilgi-iktidar" denkleminden yola çıkarak formüle etmeye çalışacağız. Ayrıca çalışmada ulaşılmak istenen amaç ise sosyal fenomenleri, Gramsci perspektifinden analiz ederek entelektüel düşüncenin (maarifçi aydınların) "hegemonik" parametreler tarafindan belirlenen tavırlarını "kültürel kimlik" tanımlarına göre mercek altına alarak değerlendireceğiz. 19. yüzyılda başlayan dönüşümün toplumsal meşruluk kazanmasına ilişkin Azerbaycan maarifçiliğinin temel epistemoloji problemi olan kimlik modelini hangi sosyal kategoride (millet, etnik, dil, din, kültür, siyasi) tanımlamak veya kavramsallaştırmak tespitleri aşağıda gösterilen varsayımlara değerlendirmeye alacağız:

Birincisi, Avrupamerkezçiliğin epistemolojik ve metodolojik problemlerini çözümleme ekseninde yapılan sorgulamalardan çıkan sonuçlarla, aslında maarifçiliğin entelektüel düşünce boyutundan daha ziyade toplumsal yapıyı dönüştürebilecek işlevlerinin hegemonik doğasını tespit etmek mümkündür. Erken dönem maarifçi aydınların tarihsel sorunları çözmeye ilişkin yürütmüş olduğu faaliyetlerde ne bir ulus-devlet modelinin inşası, ne ekonomi program taslakları, ne de kültürel kimliğin temel dayanakları konusunda ideolojik (fikir kümesi) bir görüş yer almaktadır. İkincisi ise erken dönem Azerbaycan maarifçilik konseptinde toplumun kültürel kimlik dinamikleri tarihi-geleneksel paradigmadan kopuk olarak bir sömürge "kurgusu" ve "temsili" boyutta varoluşu, muhakeme gerektiren dispositif (tertibat) düşünce ilişkilerini önemli konular arasına taşımaktadır. Milli kültürel bağlamda maarifçiliğin, düzene karşı mı, yoksa bu düzeni onaylayıcı türden mi olduğu olgusu problematik bir alan olarak çözülmesi gereken bir diğer konudur. 


\section{Maarifçiliğin Kılavuz Modeli Olarak Aydınlanma İmgesi}

19. yüzyıldan itibaren Batı kaynaklı Aydınlanma düşüncesi çeşitli isimler adı altında geleneksel anlayışa karşı ciddi bir alternatif olarak Azerbaycan'da da etkili olmuştur. Çarlık Rusyası'nın Kafkasyàyı işgalini müteakiben geleneksel bir toplumun "çağdaş" olmaya doğru teşekkül temellerinin atıldığı bu süreç (Açıkkaya 2010: 405), tarihi bağlardan kopuk bir değişikliğe yol açmıştır. Dolaysıyla hegemon güç tarafından kurgulanan eski-yeni kavgasının yansıdığı sosyal hareketlilik, sömürge güdümlü değişiklikleri kapsayacak biçimde, kozmopolit Batı kültür geleneğin yerleşmesine de imkân tanımıştır (Hodgson 2017: 231).

Genel bir ifadeyle Aydınlanma, Rönesans ile başlayan R. Descartes, J. Locke, F. Voltaire ve D. Hume'la gelişen, 1789 Fransız Devrimi ile olgunluğa erişen Batı dünyasındaki bilimsel-felsefi gelişmelerin ve sosyalpolitik süreçlerin bir bütünü olarak kastedilmektedir (Ülken 2013: 71). Aynı zamanda Aydınlanma bir çağı kapsayacak biçimde, tüm Avrupa’da etkin olan düşünce hareketine verilen isimdir. Koşullar gereği çeşitli ülkelerdeki Aydınlanma düşüncelerinin teşekkülü dönemsel olarak farklılık göstermiştir (Raynaud vd. 2003: 126). A. Çiğdem, kitabında kavramı şu şekilde tanımlamıştır: "Tüm toplumsal ilişkileri ve kurumları akılcı temeller üzerine oturtmayı hedef almasından dolayı Aydınlanma Çağı’nın diğer bir adı ise Akıl Çağı'dır." (1997: 13).

Feodal yapının çöküşüyle beraber kapitalizme geçiş sürecinde siyasi, ekonomik, toplumsal ve kültürel alanlardaki dönüşümler pozitivizm anlayışının etkisiyle yeni bir hüviyet kazanmıştır (Aliyev 2008: 40). Aydınlanma’nın bir dönüm noktası olarak kabul edilen İ. Kant'ın "Aydınlanma Nedir?” (1784) başlıklı makalesinde ortaya konan sorulara verdiği yanıtta akılcılığın merkezi konumuna dikkat çekerek, insan özgürlüğünün sınırlarını bu kavram içinde tanımlamış ve şerh etmiştir. Bu anlamda fikirlerin aydınlanması, bilimin pozitif anlayışından beslense de bu dönüşümün bir düşünce mücadelesi içerdiği konusu açık şekilde tespit edilmiştir (Raynaud vd. 2003: 127).

Geleneksel paradigmanın laik teoriyle olan çelişkisi aydınlanmanın ilerlemeci tarih anlayışı çerçevesinde yeni ikili kavramları izlemek eğilimindedir. Özellikle Doğu’ya ilişkin Batılı bakış açılarının teşekkülünde belirleyici 
rolü vardır (Turner 2003: 68). Hodgson’a göre, “...18. ve 19. yüzyılda açı ifadelerle desteklenen aydınlanma, dünyanın geri kalan bölümüne yayılması ve gelişimi bir dünya medeniyeti haline gelmiş olan Batı gücünün bir tezahürüdür." (2017: 55). Bu tanım içinde düşünüldüğü zaman kavramın taşıdığı anlam, "ötekileştirici" boyuta sahip bir söylem üzerine kurulmuş zihniyete işaret etmektedir. Avrupamerkezci düşüncesine dayanan bu süreç, "akılcılık, özgürlük, gelişim ve eleştirici dünya görüşünü temel alan, din ve dünyasal alanları ayırarak, toplumsal kurumların rasyonel yasalara göre yeniden inşa edilmesiyle oluşan birtakım sorunları kapsamaktadır" (Çiğdem 1997: 38). Ülken'in bu konudaki tespitleri çalışmamıza ş̧ı tutacak niteliktedir: "Sözünü ettiğimiz aydınlanma tabii bir fikir evriminin neticesi değil, 19. yüzyılın ortasında birdenbire dışarıdan gelen bir fikir aşısının ürünü olarak doğmuştur" (2013: 71) tezini tarihsel kurgu varsayımı olarak yorumlamak mümkündür.

Azerbaycan tarih literatüründe, Aydınlanma kavramının karşıllğı olarak atfedilen "Maarifçilik", geniş bir yelpazeye sahip olup, toplumsal hayatın her alanına ilişkin sorunlarla ilgili iki temel tanımı ihtiva etmektedir: Birincisi, dar anlamda etimoloji olarak maarif, Arapça bir kelime olan "mảrifa"dan türemiş, eğitim/bilgi/beceri anlamlarında kullanılmaktadır. İkincisi ise genel anlamıyla 19. yüzyıldan itibaren Azerbaycan'ın aydınlanması konusunda felsefi ve sosyal bir akım anlamındaki kullanımdır ki temelinde "ilerleme düşüncesi” yatmaktadır (Caferova 2016: 40).

Bu süreçte yeni entelektüel olguları öne çıkaran Maarifçilik akımı, ilerleme, hürriyet ve liberalizmle aynı mahiyeti taşısa da (Aliyev 2008: 42) muğlak bir kimlik algısı sunmaktaydı. Geleneksel toplum yapısına karşı tepkiden doğan Maarifçilik, Ramazanov’a (2001: 155) göre eğitim-öğretim ve sosyalpolitik alanlardaki laik değişimlerin öncüsü olarak üç aşamada gelişimini sürdürmüştür:

Birinci aşama: Erken Dönem Maarifçiliğin teşekkülü 1830’lardan başlayarak 1850'lere kadar olan bir dönemi kapsamaktadır. Bu aşamada M. Ş. Vazıh (1794-1852), A. Bakıhanov (1794-1847), M. Kâzım Bey (1802-1870) ve M. C. Topçubaşov (1790-1869) gibi aydınlar faaliyetleriyle ilk çağdaşlaşma yolunu açmışlardır. İlk aşamada din ve gelenek alışkanlıkları yerini, aklın ve özellikle bilimsel ölçütlerin üstünlük inancına bırakmıştır. Bu ölçütler tarihsel harekete yeni bir ivme katarak hegemonyanın tasarlamış olduğu sürecin ve 
değişimlerin teşekkülünü olanaklı hale getirmiştir. Kültür, tarih, dil, folklor ve edebi metinlerin tetkik edilmeye başlanması sömürgeci kurumların oryantalist çalışmaları olarak ön plana çıkmıştır.

İkinci aşama: 1850-1870 tarihlerini kapsamaktadır. Bu aşama aydınlanmanın yetkin dönemi olarak Batı'nın bilim ve felsefe alanındaki kuramlarının kabul edilebilmesini içermekte ve metafizik görüşe karşı maarifçiliğin müşterek fikirlerine tevafuk etmektedir. Üzerinde durulması gereken esas hususlardan biri düşünce gelişiminin temel olgusu olan "dil” ve "yazı” sorununun çözümüne yöneliktir. Diğer bir sorun ise Batı eksenli Aydınlanma paradigması ile bağlantılı olarak din ve kültür konuları materyalist düşünceler temelinde yer almıştır. Dil, tarih, coğrafya, edebiyat, sanat vb. alanlarındaki gelişmeler, tarihsel-siyasal ölçütün ana hattı olarak Avrupamerkezçi perspektif üzerinde konumlandığını söyleyebiliriz. Bu dönemin en önemli siması M. F. Ahundov idi.

Üçüncü aşama: 1870-1900 yıllarını kapsayan maarifçilik çalışmaları, siyasi, ekonomi ve sosyal yapıdaki dönüşüme sağladıkları katkılardan daha ziyade kültürel kimliğin oluşumuna dair fikir alanında önemli gelişmelere yeni ivme katacaktır. Zira Batı'ya açık Ceditçi olarak nitelendirilen fikir hareketinin (Türkçülük) temsilcileri (Hasan Bey Zerdabi, İsmail Bey Gaspıralı, Yusuf Bey Akçura, Ali Bey Hüseyinzade, Ahmet Bey Ağaoğlu, Mehmet emin Resulzade vb.) faaliyetlerini Azerbaycan'da milli kimlik olgusunu bilimsel metodolojik çerçevede kavramsallaştırmak üzerine inşa edecektir. Amaç ise sömürge gücün böldüğü Türk-Müslüman toplulukları bir araya getirebilmek ve bir "millet” şekline sokabilmektir. Nitekim bu aşamada Türkleşmek, Çağdaşlaşmak ve İslamlaşmak temel bir ilke olarak yeni bir dönemin zeminin oluşturacaktır.

Tamamlanan her bir aşamadan diğerine geçişin nedeni düşünsel krize bağlı diyalektik olaydır. Bu kriz geniş ölçekte kavramsal ve kuramsal sorunları da beraberinde getirmiştir. Üç aşamanın birincisinde, aydınlanma; ikincisinde, halka doğru yönelim; üçüncüsünde ise siyasi-ideoloji özgürlük teşekkül etmiştir. Böylece, Berkes’in belirttiği gibi: "Batı terimleriyle bu aşamaları rasyonalizm, demokrasi ve liberalizm olarak nitelendirmek mümkündür.” (2012: 253). 
Dinin merkezde olduğu bir dünya görüşünden aklın merkezde olduğu bir dünya görüşüne geçiş sürecinde hem Rusya hem de Türkiye aydınları ile kurulan temaslar Azerbaycan Maarifçilik akımının teşekkülünde belirleyici amildir. Temel ve asli nitelikteki ilişkiler dâhilinde doğan bu temasların, tarihsel seviyede birbirlerine kesin biçimde bağımlı olmadıklarını açı söyleyebiliriz.

Rusya etkenli aydınlanma olgusu Azerbaycan Maarifçiliğini doğrudan kültürel saptırma üzerine bina etmeye çalışmışıı. "Kültürel kimliğe uygun kavramları arama çabalarına son vererek, derin tarihsel süreçleri görmezden gelmişlerdir." (Hodgson 2017: 405). Onların bu düşüncesinin muhtevasında I. Petródan (1672-1725) başlayan modernleşme hareketinin itici gücü ağırlık kazanmıştır (Berdiaev 2008: 177). Aynı zamanda Rus aydınlarının ekseriyetinde Batı düşüncesinin kabul edilmesi durumu Rusya’nın güçlü bir modern devlete ulaşacağına dair kanaati yaygındır. Napolyon Savaşları'nı (1803-1815) müteakip Rus aydınlarının tartışma konusu haline gelmiş en temel sorunların (milli kimlik olgusu, Fransız kozmopolitik anlayışı) Alman felsefesinden (Rusların çoğu Almanya'da eğitim görüyordu) kaynaklanması kuvvetle muhtemeldir (Kolosov 2000: 268, Ortaylı 2016: 17).

Rusya'da yeni fikirlerin üretildiği bir döneme işaret eden modernleşme süreci, içerdiği karmaşıklıktan dolayı dengeden uzak farklı durumu ortaya çıkarmış ve göz ardı edilmeyecek birçok çatışmalara olanak sağlamıştır. Çar I. Aleksandr'ın ölümü üzerine meşrutiyet yanlısı yüksek askeri subayların ve aydınların Aralık 1825 'te başlattığı ayaklanma hareketi (ilgili ayaklanma tarihe "Dekabristler" yani "Aralıkçlar" isyanı olarak geçmiştir) sonucunda hapsedilen isyancıların önemli bir kesimi Kafkasya’ya sürgün edilmiştir. Diğer bir taraftan ise Rusya'nın Lehistan'ı işgali (1830) üzerine ayaklanan Leh direnişçilerin hapsedilerek Kafkasya bölgesine sürgün edilmesiyle kurulan temaslar (Kasımzade 1956: 67), Azerbaycan'da aydınlanmanın ilk kıvılcımlarına dönüşmüştür. Kafkasyàya, özellikle Tiflis şehrine sürgün edilen çok saydaki direnişçiler arasında bulunan akademisyen ve entelektüellerin bölge aydınları ile temasları, esaretteki halkların düşünce uyanışı açısından önemli bir safha oluşturmuştur. Örneğin, A. BestujevMarlinskiy ile Ahundov'un arasındaki dostluk ilişkileri (Aliyev 2008: 45) onun Avrupamerkezci eğiliminde belirleyici rol oynamıştır. Azerbaycan maarifçilerinin sosyal-politik bakış açılarının teşekkülünde ve entelektüel 
seviyelerinin gelişiminde dönemin idari ve kültür merkezi sayılan Tiflis şehrinin sosyal-kültürel hayatı bir çekim gücü olarak önemli etken olmuştur (Alimirzayev 2007: 8)

19. yüzyıl Rusya aydınları ve aydınlanma hareketinin karakterine ilişkin Gramsci, kendi doğruluk değerleri içinde şöyle bir tespitte bulunmuştur: "Rusya'da Aydınlanma konsepti, yabancı etkileri Ruslaştırarak, onları bütünüyle kendi içlerinde eriterek, 'özsel' bir 'ulusal' niteliğe bürümüştür." (1986: 329). Bu bağlamda, Rus aydınları ile olan aradaki bağ ister açık, isterse de kapalı olsun, pratik bakımdan en etkili biçimde kendini var etmemiştir. Bu sorun kısır polemikler dizisine yol açmış ve hegemonik zihniyetin içerdiğini özneler şeklinde ortaya çıkarmıştır.

Rusya Müslümanları arasında aydınlanma, tek bir merkezde değil birbirinden bağımsız farklı mekânlarda doğup gelişmiştir. Bu mekânlar Türkiye, İdil-Ural ve Azerbaycan olarak sıralanabilir (Gündoğdu 2008: 42). Rusya, hâkimiyetine aldığı Türk-Müslüman topluluklarını eğitimsiz ve geri kalmış duruma mahkûm etmekle kalmamış, yeni nesilleri kendi dünya görüşü çerçevesinde "Ruslaştırarak" yetiştirme amacını gütmüştür. İ. Gaspıralı'nın (1851-1914) başını çektiği Aydınlanma (Ceditçilik) hareketi Rus coğrafyasındaki Türkler için yeni bir intibah yolu açmıştır. İlk adımı Bahçesaray'da atıldığı Usul-i Cedit okullarının Azerbaycan toplumunun aydınlanmasındaki hizmeti eşsizdir (Kastrati 2017: 266). Akçura'ya (1928: 342) göre, "Usul-i Cedit' in gerçek anlamı Batı bilimini, eğitimini ve yaşayış tarzını benimsemek, kısacası modernleşmektir. Rusya Türkleri kendi kültürel kimliğini muhafaza etmek koşuluyla Batılılaşma taraftarı olmuş, gayretlerini bu istikamette yoğunlaştırmıştır." Gaspıralı'nın çıkardığı "Tercüman” (1883) gazetesinin dilde, fikirde, iş̧te birlik ilkeleri etrafında oluşmuş faaliyeti müşterek kültür temelinde biçimlenmiştir. "Biz kimiz, nereden gelip nereye gidiyoruz?” sorusu aktüellik kazanmış ve tarihsel yanıtları milli kültürün temel parametrelerinde aranmıştır.

Batı düşüncesinin idealleri üzerinde kurulmuş Azerbaycan Maarifçiliğine Türkiye'nin katkısının ne zaman başladığı konusu üzerine uzlaşılan bir başlangıç noktasının olmamasına rağmen, etkinin yoğunluk derecesine bağlı olarak farklı dönemlere yaymak mümkündü. Türkiye'nin "Batılılaşma" serüveninin en önemli istikametlerinden biri olan Aydınlanma, Batı kültür çevresinin son yüzyıllardaki en etkin düşünce akımı idi (Ortaylı 2016: 15). 
Bu dönüşümün Türkiye karşısına çıkardığı problemlerin, Batılı halkların karşısına çıkardığı problemlerden tamamen farklı olması gerçeği, tarihle olan farklı ilişkiden kaynaklanmaktaydı (Hodgson 2017: 385). Bu anlamda, Yeni Osmanlılar olarak tanıdığımız grup, ideolojik düşüncelerini Batı’dan alınmış kavramlar içinde İslam terminolojisi ile ifade edecek bir Aydınlanma düşünce perspektifi ortaya koymuşlardı (Mardin 2013: 11).

Türkiye Azerbaycan ilişkilerinin durumu ile ilgili 19. yüzyılın ikinci yarısını kapsayan bir dönemi ele alan Yavuz Akpınar, Azeri Edebiyatında Namık Kemal adlı makalesinde konuya şöyle değinmektedir: "Çok az sayda olsalar da bazı Azerbaycan aydınlarının Namık Kemal'i 1873'deki Vatan Yahut Silistre’nin kopardığı fırtına sebebiyle tanımış olduklarını tahmin edebiliriz. O dönemlerde Çarlık sansürü sebebiyle Türkiye ile bağlı haberlere ver verilmediği kesin bilinmektedir. Azerbaycan’la Türkiye arasındaki yakın bağlar bu şekilde düşünmemize imkân veriyor ki Rus sansürüne rağmen Azerbaycan okullarında Türkiye'den getirilmiş çok sayda kitaplar gizlice okutulmuştur." (Akpınar 1994: 216'dan akt. Nağıyeva 2017: 68).

Osmanlıcılığa karşı Türklüğü savunan Ali Suavi (1838-1878), Osmanlı dışındakiTürk-Müslüman aydınları ile daima temas halinde olmuştur (Berkes 2012: 285). Ahundov'un 1868'de Londra'da çıan "Muhbir" gazetesine yazdığı "Suavi Efendi'nin Akidesine Karşı Tenkit" adlı yazısında Arap alfabesinin sslah edilmesi ve yazı üslubunun değiştirilmesi tasarısı üzerine yetersiz bulduğu tarafları ironik bir biçimde ele alınmıştır (Ahundov 2005: 225). Çeşitli siyasi-ideoloji görüşlerin (İslamcılık, Batıcılık ve Türkçülük) çatıştı̆̆ bu dönemde onların uzlaştırılması ve birbirini tamamlayan üç görüş olduğu tezini ileri süren ilk aydın Ali Suavi'dir. Namık Kemal ve Ziya Paşa, yeni Osmanlı Devleti'nin Şeriat temelinde olmasını arzu etseler de Ali Suavi dünyanın dinle idare edilmesine karşı yazılarına devam etmiş ve laik meşruti idare fikrini savunmuştur (Mardin 2015: 88). Ülken’e göre "Ali Suavi ilk Türkçülerden biri olarak Osmanlıcıllğa karşı Türklük fikrini ileri sürmüştür." (2013: 91).

Bu yeni dürtüler eski kurumlar dâhil tüm değerleri birbirine karıştırarak, kendine özgü bir ahlaki disiplini onun yerini doldurabilecek konuma getirmiştir. $\mathrm{Bu}$ süreçte doğan, geleneksel ile modernitenin, din ile sekülerizmin arasındaki çatısmalar bir sıra kavramsal problemlerin kalıcılığına yeni çıkarımlar sağlamıştır. Ayrıca, Azerbaycan'da sömürgeci 
politikaların uygulanmaya konması ile maarifçiliğin doğması arasındaki eşzamanlılık, hegemonik konseptin tam olarak ne anlam ifade ettiğini, Osmanlı örneğinde algılamak, sürecin genel portresini çizmek bakımından yeterli olacaktır.

\section{Maarifçilik Portresinde Hegemonik Çizgiler}

Geleneksellikten modernleşmeye geçiş sağlama düşüncesi ile yapılan faaliyetler, çizilen imgeler ve toplumsal katmanları oluşturan tüm ögeler arası ilişkilerde egemen güce ait izlere rastlamamak mümkün değildir. Buradan hareketle geleneksel anlayışı tarihin dışına iten etkenleri yüzeye çıkarmak için Foucault'nun bilgi-iktidar çözümlemelerine bakmak gerekmektedir. Foucault çözümlemelerinde yer alan dispositif (tertibatlar, mekanizmalar) kavramı, konjonktür değişmelerine paralel olarak değerlerin ne olduğunu açıllamak ve bu değerleri tahribata uğratacak güç aygıtlarını tespit edebilmek noktasında belirleyicidir. Azerbaycan maarifçiliğinin karakteristik özelliğini ihtiva eden geleneksel yapıya karşı mücadelesi bu çözümlemeyle açığa kavuşturursak, çalışmamızın nesnellik bakımında bir sonucunu ortaya çıkarabiliriz. Özellikle din ve kültür olgusunun geri kalmışlığın en önemli sebebi olarak gösterilmesi maarifçilerin sarıldıkları temel sütundur (Aliyev 2008: 43).

Avrupamerkezcilik (Avrupamerkezcilik, tarihsel ilerleme çizgisinde Batı'nın üstünlügünü hedef alan bir tahakküm etme teorisi ve stratejisidir - Lacoste 2014: 169), eğiliminde eğitimin ve aydınların rolü modernleşmenin itici güç parametrelerindendir. Konunun aydınlatılması açısından Gramsci'nin çözümlemelerinden yola çıkarak, aydınların özerk ve bağımsız bir grup mu olduğu, yoksa her toplumsal grubun kendine özgü aydın kategorisi mi vardır? sorusu karmaşıklığı ile birlikte üzerinde durulması gereken hassas bir problemi içermektedir. Bu soruya Gramsci'nin verdiği yanıt ise şöyledir: "Kökensel alan üzerinde doğan her toplumsal grup, kendisiyle birlikte organik olarak, yalnız ekonomik alanda değil, siyasal ve toplumsal alanda da kendi öz işlevinin bilincini veren birçok aydınlar katmanını yaratır." (Gramsci 1986: 309).

Avrupamerkezcilik hegemonyası varsayımı üzerine kurgulamış modernleşme, Foucault'nun belirttiği gibi, güç kendi dispositif ilişkiler ağını oluşturmak için insanı biçimlendiren, yöneten, bağımlılaştıran veya tabi kılan çok çeşitli 
güç aygıtıdır (Kızılkaya 2013: 21). Kültürel ve entelektüel ögeler üzerine kurgulamaktadır. Gramsci'nin "Hapishane Defterleri” yazı notlarında ise "aydın" kavramı, organik ve geleneksel, rıza, baskı, sivil toplum, siyasal toplum ve Doğu-Batı ilişkilerindeki minval "hegemonya" matrisi üzerinde çizilmektedir. Böylece farklı biçimler altında ifade edilen "hegemonya" kavram, 19. yüzyıldan beri tek bir biçime, tek dünya görüşünün örgütlenmesine, tek medeniyet tipinin oluşumuna olanak sağlayan tarihsel metinler içinde kategorize edilmektedir (Foucault 1999: 26).

Çarlık Rusyası, Azerbaycan'da sosyal-ekonomik istinatlarını güçlendirmek adına, bürokrasi ve idari uygulamalara ağırlık vermiştir. Daha sonra "medenileştirme" ve eğitim gibi sosyal-kültürel konuları gündemine almıştır (Velihanov 1983: 99). Yani egemen güç, toplum üzerinde siyasi-kültürelekonomik egemenliği tesis edebilmek için yeni tipli kadroları yetiştirme çalışmaları, kültürel hegemonya konsepti içerisinde şekillenmiştir. Eğitim ve öğretim en etkili entelektüel araç olarak kullanılmıştır (Gramsci 1986: 319).

Örneğin, Rus eğitimcisi N. İlminskiy’nin Rus olmayan halkların eğitimi için 1859 'da sömürüye uygun şekilde yeni bir okul müfredatı hazırlamak teşebbüsü ve yaptığı çalışmalar hegemonya unsurlarını destekler nitelikteydi. İçerisinde yeni alfabe konusu öncelik taşımaktaydı. En dikkat çeken çalışmalardan bir diğeri ise Ortadoks Hristiyan eser ve dualarının mümkün olduğu kadar halkın anlayacağı ve benimseyeceği bir şekilde Arap alfabesiyle yayınlanmasıydı (Can 2017). Rus olmayan halklar arasında ilk aydınların yetişmesine ilişkin İlminskiy’nin başarısı devlet tarafından takdirle karşılandı. "Uçitelskaya Seminarya" gibi okulların yaygınlaştırılması İlminskiy'e telkin edildi (Zenkovsky 2000: 44). Böylece yerli entelektüellerin kültürel yapıdan kopuk seküler bir tavır içinde yetiştirilmesi ve onların Avrupamerkezci ilkeleri benimsemiş olmaları merkezi güç yönetimi tarafından pek rağbetle desteklenmekteydi (Buttigieg 2012b: 282).

Nihayetinde maarifçilik faaliyetlerinin etkisi altında şekillenen ideoloji muhteva toplumu kurtaracak unsurları dışarda aramaktaydı. Müslüman halkını Rusya medeniyetine entegre edilebilme bilinci tam manasıyla benimsenmekteydi (Abdullayeva 2014: 21). Kısaca özetlersek, Azerbaycan’da Aydınlanma "hareketi önerilmemiş, aksine tasarlanmıştır" tezi doğrulanmış bir varsayımdi. 
19. yüzyılın ilk çeyreğinden itibaren yeni teşekkül etmeye başlayan maarif̧̧i aydınlar zümresi ilk başlarda edebi yol izleseler de sonralar memur hüviyetleriyle sosyal bir veçhe kazandılar. İlk temsilcilerinden Abbaskulu Ağa Bakıhanov, 1826-1828 Rus-İran ve 1828-1829 Rus-Osmanlı savaşlarını müteakip yürütülen barış görüşmelerinde General Paskeyeviç'in maiyetinde mütercim olarak bulundu. Rusların Erzurum ve Beyazıt'ı işgali zamanı ganimet olarak ele geçirilen nadir belge ve metinlerin Petersburg'a götürülmesi çalışmalarında bir proje yürütücüsü olarak görev aldı (Barthold 2004: 384). Sömürge savaşları sonucunda ele geçirilen Doğu kültürüne ve tarihine dair metinlerin Bakıhanov tarafindan bilimsel tetkike tabi tutuldu (Velihanlı 2014). Kafkasya tarihi ile ilgili Bakıhanov'un Gülistan-ı Irem (1841) kitabının hazırlanması bir bakıma elde edilen belgelerin yorumlanmasıyla bağlıydı (Bakıhanov 2005: 9). Kitapta Azerbaycan tarihine ilişkin yeni yöntem ve dönemsellik tarihsellik açısından önem arz etmekteydi. İlk kez Kafkasya'ya ve Azerbaycan'a ait konular mümkün olduğu kadar Batı metotlarıla tetkike alınmaktaydı.

Mirza Kâzım Bey’in sunduğu düşünce örgüsü, bilim, din ve kimlik olarak tabir edilen anlayışın tuhaf karışımını (1823 yılında Hristiyanlığı kabul etmiştir ve Aleksandr Kâzım Bek olarak bilinir - Kanlıdere 2012: 164) ihtiva etmektedir. Adı en çok Azerbaycan Türkçesi'nin (Türk-Tatar Dilinin Grameri eseri 1839'da yayımlanmıştır) yeni yöntemlere dayanan çalışmalarıyla ünlüdür. Ayrıca Kazan ve Petersburg Üniversitelerinde (M. C. Topçubaşov'dan sonra) ilk Azerbaycanlı profesör olarak görev almışır (Baykara 1975: 71). Doğu dilleri ve İslam hukuku araştırmacısı olan Mirza Kâzım Bey, Rusyàda Şarkiyatçılık okulunu kurucusu olarak, ortaya koyduğu zengin bilimsel araştırmalarla sonraki neslin yetişmesinde önemli rol oynamıştır (Kasımzade 1956: 54). Kafkasya’nın tarihi ve coğrafyası konusunda değerli bilgileri içeren Derbentname eserinin Rusya Oryantalizminin tarihsel gelişiminde etkisi eşsizdir. Derbent tarihini anlatan bu eserin Farsça metinlerini diğer nüshalarla karşılaştırarak edisyon kritiğini yapmış ve yeni bilgiler ekleyerek Fransızca ve İngilizceye çevirmiştir (Rzayev 1965: 143).

Azerbaycan maarifçiliği, Mirza Fetali Ahundov'un simasında kendi olgunluk dönemine ayak basmıştır. Ahundov, modern edebiyatın kurucusu, edip, şair ve materyalist filozof olarak 19. yüzyıl Doğu dünyasının siyasi- 
felsefi düşünce tarihinde önemli yere sahiptir. Yaşamının amacını toplumsal muhakeme olduğunu göstermeye çalışarak geçirmiş, kendine özgü tavır ve üsluba sahip çok yönlü özgün bir kişiliktir. Felsefi materyalist bakış açısına istinaden yazmış olduğu eserlerin ve geleneksel yaşam tarzını ötekileştirmeye dönük eleştirilerin yanı sıra Çarlı̆̆ın Doğu’ya dönük siyasetinde etkin bir rol üstlenmiştir. 1846 'da Rusya-İran devletleri arasında yürütülen diplomatik müzakerelerde tercüman olarak görev almıştır (Kasımzade 1956: 264).

Ahundov'un, 1857 yılında kaleme aldığı Aldanmıs Kevakib adlı eseri, 19. yüzyıl Azerbaycan edebiyatının ilk hikâye örneği olarak yazılmıştır (Kasımzade 1956: 325). Siyasi ve toplumsal görüşlere yer verdiği bu eserinde, Doğu'daki idari sisteme ve yönetime karşı muhalif yönünü ortaya koymuştur. Doğu'nun toplumsal hayatı, halk ve iktidar katmanları arasındaki çok çizgili ve karmaşık ilişkileri dinin etkilerine bağlamıştır.

Yazar, Kemalüddövle'nin Cemalüddövle’ye Mektupları ve Cemalüddevle’nin Cevapları adlı felsefi içerikli eseriyle Doğu'daki hayatın geri kalmışlğ̆ını bütün boyutlarıyla göz önüne sermeye çalışmıştır. İsakov'a yazdığı bir mektupta Doğu'nun sorunlarını şu şekilde belirtmiştir: "Doğu'nun durgunluğu, despotizmin doğuşu ve genellikle Asyalıların medeniyete ve gelişmeye karşı kayıtsızlığının kökenleri ve nedenleri (...) Araplar ve onların insan doğasına uygun olmayan menfur dinidir. İnsanlığın saadeti ve kurtuluşu, ister Batı’da isterse de Doğu'da olsun dinde değil, rasyonel düşüncede olduğu telakki edilebilir." (Ahundov 2005: 188).

Alfabe 1slahatı ile bağlı olarak 1863 'te İstanbul'a gelen Ahundov, dönemin sadrazamı Fuad Paşa tarafından kabul edilmiştir. Hazırladığı alfabe taslağı siyasi çevrelerde gerekli desteği görmese de Sultan Abdülaziz tarafindan Mecidiye nişanı ile onurlandırılmıştır (Akpınar 1980: 60). Nitekim 1873'te İstanbul'da çıkan Hakayık gazetesine gönderdiği mektupta ise Müslümanların Arap alfabesini kaldırarak yerine Latin alfabesinin kullanılması meselesini gündeme getirmiştir (Caferova 2016: 37). Ahundov, birçok makale ve mektuplarında toplumsal sorunların çözümünün ancak Çarlık Rusyası himayesinde mümkün olabileceği tezini savunmuştur (Aliyev 2008: 44). Bu görüş doğrultusunda çağdaşlaşma düşüncesi ve idealleri maarifçi kesim üzerinden topluma dayatılarak yeni bir muhitin teşekkülüne zemin hazırlamıştır. 
Azerbaycan Maarifçiliğinin üçüncü ve son devri 1870-1900 yıllara tesadüf etmekteydi ki bu devirde maarifçilik Ahundov'un manevi varisi Hasan Bey Zerdabi’nin simasında gelişme göstermiştir. Anadili saflığının korunması, kültürel kimlik bilincinin uyandırılması ve milli basının gelişmesi konusunda Zerdabi'nin hizmetleri müstesnadır (Kasımzade 1956: 63, Caferoğlu 1964: 14). 1873 'te N. B. Vezirov'un desteğiyle sahneye konan Ahundov'un $\mathrm{Hact}$ Kara adlı piyesinin sergilenmesi Azerbaycan tiyatro sanatının ilk oyunu olarak Zerdabi'nin katkısıyla gerçekleşmiştir.

Zerdabi, Ahundov'un maarifçilik geleneğine bağlı kalarak, Azerbaycan'da yerli basının teşekkülünü bir memur çabasıyla gerçekleştirdi. Çarlık idaresine yaptığı müracaat sonucunda 22 Temmuz 1875 'te Ekinçi gazetesinin ilk sayısı 1şık yüzü gördü (Hüseynov 2007: 282). Rusya Müslümanları arasında çıan tek Türkçe gazete olan Ekinçi gazetesi kendi sayfalarında sade ve halkın anlayabileceği dilde yayımlanan yazılarla sesini halka duyuruyordu. Ziraat, ekin, köy hayatı ve dünyada baş veren bilimsel yenilik haberlerine paralel olarak geleneksel yapının kemikleşmiş yanları ve dini sömürüyü eleştiren makaleler sınırlı bir etki alanına sahipti. Zerdabi, İslam’n dini köklerine ve esaslarına karşı, Ahundov'dan farklı bir tutum sergileyerek saldırmaktan kaçınmıştı. Zerdabi'nin toplumsal değerleri esas alarak farklı konularda yazmış olduğu yazılar bir mücadelenin temel dinamiği olarak öne çıkmaya başlamıştı. Kiev şehrinde öğrenim gören Azerbaycanlı öğrenciler tarafından toplanan Zerdabi'ye ait yazılar bir kitap haline getirilerek basılmıştı (Caferoğlu 1964: 14).

Azerbaycan Türklerinin asimile edilme tehlikelerine karşı tahammül etme aşamasından Zerdabi'nin katkılarıyla milli uyanış aşamasına geçiş önemli milli kültürel kazanımlardan biri olmuştur (Elyarlı 1991: 35). İlk iki aşamadaki "...maarifçilerin karamsar, edilgen, yakınma ve serzeniş içerikli yaklaşımları yerini Zerbabi'nin mücadele içeren sorgulayıcı eylemlerine bırakmıştır." (Nasipli 2001: 141). Dolayısıyla Zerdabi'nin, geleneksel eğitimin toplum hayatındaki rolünü sınırlandırmak ve yerine yenilikçi yöntemlere istinaden Avrupamerkezci laik eğitimin konulması noktasındaki önerileri eğitim düzenlemelerinde çok etkili olmuştur (Erol 2006: 61).

\section{Maarifçilikte Kültürel Kimlik Problemi}

Kültür, etimolojik olarak Latince culture, "toprağ1 sürmek, ürün elde etmek ve onları geliştirmek" anlamına gelen kelimeden türemiştir. Kültür 
kavramını, toplumsal değişim sürecinde maddi ve manevi alanlarda oluşturduğu ürünlerin tümü, temel ihtiyaçları elde etmek için kullanılan yöntemler; fikirler, bilgiler, inançlar; geleneksel, dinsel, sosyal-politik düzen ve kurumlar; düşünce, duyuş, tutum, davranış biçimleri ve yaşam tarzı olarak tanımlamak mümkündür (Larrain 1995: 217).

Kavramların, içinde doğduğu sosyal-kültürel muhitin özelliklerini taşıdığ prensiplerden hareket edildiğinde, farklı sosyal-kültürel yapıların, farklı bağlamlarda değerlendirilebileceği yadsınamaz bir gerçekliktir. Değişen koşullara rağmen milli kimliğin tanımlanması ideolojik esasların aksine, kültürel derinlikteki katmanların, normların, statülerin ve inançların belirleyici olduğu değerlere göre şekillenmiştir (Erkal 1998: 139). Dolayısıyla kültürün tüm katmanlarını oluşturan dil, din, örf ve adetler, belirli bir edebiyat ve sanat anlayışı gibi ögeler tek başına ele alınmaz, bir bütünü kapsamaktadır (Guibernau 1997: 127). Modernleşme anlayışında kültürel kimlik örüntüleri ulusalcı modelin parametreleri ile değil, kapsayıcı, evrenselci bir kültür ve toplum çizgisinde var olmaktadır (Abou El-Haj 2000: 113). Foucault'nun vurguladığ 1 gibi her bir dönemin epistemik düzlemi ve onu inşa eden kültür kodları “...yaşamın bütünselliği içinde bilgi alanını sınırlayan, bu alanda ortaya çıkan nesnelerden olma biçimini tanımlayan, insanoğlunun günlük kavrayışını kurumsal güçlerle donatan ve doğru olarak görülen şeyler hakkında insanoğlunun geliştirdiği bir söylemin koşullarını tanımlayan tarihsel 'a priori'lerdir." (Bozkurt 1988: 42).

Genel Türk kültürü çerçevesinden baktığımızda modernleşmenin getirdiği kültürel değişim süreci çok ciddi sıkıntıları da beraberinde getirmiştir. Türk İslam kültürü, Bozkır, İslam ve Batı medeniyeti olmak üzere üç temel dalganın etkisi altında dönüşümünü sürdürdüğüne dair kabul edilir bir kanaat hâsıl olmuştur (Horata 2017: 120). 19. yüzyıl Azerbaycan tarihi açısından baktığımızda ise Rusya, hem askeri hem de sosyalkültürel alanlarda egemenliğini sürdürmek için kültürel kimliği oluşturan unsurları tahrip edebilen politikaları en radikal şekilde ortaya koymuştur (Hacısalihoğlu 2012: 41). Çarlık yönetimi, Kuzey Azerbaycan’a tamamen egemen olabilmek için buradaki Türkiye ve İran'ın kültürel tesirini yok etmeye yönelik çalışmalarını daha da ileri noktalara taşınmıştır. Bu amaçla Azerbaycan'ın idari işlerinde ve resmi yazışmalarında kullanılan Farsça ve Osmanlıca yasaklanmış (Zenkovsky 2000: 94) ve 1870'te Rusçanın 
kullanımı zorunlu hale getirilmiştir. Çarlık Rusyası' nın yayılmacı hareketiyle birlikte ülkede dini ve milli bütünlük sarsılmış ve yürütülen "1slahatlar" kültür politikaları çerçevesinde biçimlenmiştir (Mahmudov 2005: 24).

Maarifçilik kritiğine karşılık kültürel kimliğin tanımı, yapısı ve mahiyeti, merkezi kurumlarca benimsenen "kozmopolit" görüşlerin tehdidi altında yok edilme tehlikesi ile karşı karşıya kaldığı açık şekilde görülmektedir. Azerbaycan Maarifçiliğinin geleneksel sosyal yapıyı dönüştürme çabaları, yeni kimlik arayışı ve aydınlanma yolunda atılan adımlar, Avrupamerkezci görüş doğrultusunda ileri aşamaya taşınmıştır. Özellikle dış dinamiklere bağlı olarak yapılan müdahaleler, düzenlemeler ve dayatmalar sonucu ortaya çıkan topluma yönelik "yeni kimlik" algısı gerçeği tüm toplumsal ve kültürel söylem tarzlarını şöyle değiştirmiştir:

Birincisi, Rusya sömürgesiyle başlayan Oryantalizm çalışmaları sosyalkültürel alanları mercek altına almakla kültürel kimliği sömürge kimliğine dönüştürme hedefi vazgeçilmez bir ölçüttü. Tarihsel ve kültürel kavramların tahrip edilmesi bu durumu teyit etmekteydi. Yeni dönemin özelliklerine ve taleplerine uygun bir şekilde çeşitli kavramlar inşa eden egemen güç, dine ve kültüre karşı muhalif bir mevkideydi. Dönem itibariyle maarifçilik anlayışı çizgisinde yapılan Oryantalizm çalışmaları bu değişimin kırılma noktalarından biriydi. Böylece Çarlık Rusyası'nın yayılmacı etkisiyle toplumsal homojenlik dağılmış, uygulanan milli kültürü yozlaştırma politikalarında entegrasyon kuramı belirleyici bir öge olarak ortaya çıkmıştı. Yani yeni kimlik Avrupamerkezciliğin kozmopolit temelleri üzerine kurgulanmaya çalışılmıştı. Bu süreçte Tatar kimliği ve dili, kurgulanan kimliğin tanımı olarak hegemonya düzlemi içinde öne çıkarılmıştı. Gramsciyen teoriye göre bu dönüşüm sırasında sömürgeci güç çizdiği imgelerle hegemonik boyutu yeni bir amaca doğru itmişti. Bu durumda hegemonyanın geleneksel yaşam tarzını ötekileştirmeye dönük çabası ile Avrupamerkezci toplumlarının rasyonel gerçekliğini üreten olgular arasında bir özdeşlik söz konusu olmuştu.

İkincisi ise Çarlık Rusyası'nın Azerbaycan'a ve diğer sömürge bölgelerine yaklaşımında "medenileştirme" politikalarının formüle edildiği tarif maarifçilik çalışmalarının muhtevası düzeyindeydi. Ayrıca egemen gücün varlı̆̆ına ilişkin maarifçilerin Rus aydınları ile ortak bir algıyı paylaşmaları bu minval üzerineydi. Ortaya çıkan tutarsılık ise "kimlik" kavramını bazı 
hâllerde mezhepsel kategoride, bazı hâllerde de küçük etnik kategoride tasnif etmekten ibaretiydi. Çünkü mezhepsel (Şii ve Sünni dengesi) oluşumların düşünce ve yaşam biçimleri üzerindeki etkinliği ve belirleyiciliği sömürge çıkarlarına uygun duruma getirilmişti. Etnik, dinsel ve mezhepsel gruplara göre farklı politika sergilemesinin olumsuz etkisi toplumsal düzeyde kopukluğun derinleşmesine yol açtı. Nitekim Said'in, Oryantalizm araştırmalarında sömürgecilik mantığını çözen açıklamaları şöyledir: "... uygulama düzeyinde olup bitenler, kuram düzeyindekinden çok karmaşıktı.” (2016: 19). Karmaşıktan doğan ayrıntılar, boşluklar ve kırılmalar geniş ölçekli kültür ve düşüncelerin hegemonyasına göre kurgulanmaktaydı. Yani toplumsal bilgi üretilirken meydana çıkan tüm ayrışmalarda (din, mezhep, etnik kimlik) örgütlenmiş siyasal ve askeri mantığın gizlendiğini açık görmek mümkündü.

Tarihi sürecin bir hedefe doğru ilerleme (Carr 1996: 125) varsayımı, Batı medeniyetinin üstünlüğü algısına uygun sistematik bir biçimde işlenmiştir (Şimşek 2007: 16). Aynı şekilde tarihsel arka planda örülmüş imgesel ilişkiler ağı Batı'nın ideolojik karakterine meşruluk olanağı sağlama amacını gütmüştür (Hobson 2015: 21). Foucualt'nun bilgi-iktidar denkleminden yola çıkan Said, "Oryantalizm” kitabında kültürel emperyalizme dair tespit ve tasnif çalışmaları, sorunun çözümlenmesi istikametinde yeni bir bakış açısı sunmuştur (2016: 22). Ayrıca iktidarın sömürge halkla arasındaki bağı güçlendirmeye dönük hegemonya çalışmalarında gizli ideolojik işlemin uygulandığı sınırlar, filoloji, folklor ve etnografya gibi alanlara doğru kaymıştır. Bu bağlamda Radloff (1837-1918) ve takipçileri tarafından Türk etnik kökenine dayanan grupları daha sonradan "Türkleşen” kavimler olarak tanımlama çabaları, akademik anlayıştan kopuk bir durumu gözler önüne sermiştir (Aça 2004: 27-28). Oryantalist çalışmaları için seçilen Rus bilim adamları kendi esareti altındaki Türk ve Müslüman toplulukların tarihi-kültürel zenginliklerini incelemekten ziyade, onların dil, edebiyat ve sosyal hayatlarındaki farklılıklarla daha fazla ilgilenmişlerdir. Türkoloji'nin Rusya'da çok köklü bir temele oturmasının nedenlerinden biri de bu olmuştur (Devlet 1994: 6). Oryantalistler tarafından Azerbaycan'da "kimlik" kavramına dair çalışmaların önemli boyutunu teşkil eden, dil ve din olgusu yukarıda kaydedilen anlayış kapsamında incelemeye alınmıştır. Edebiyat ve fikir sistemlerinde modernleşmeyi teşviki konusu ideolojik bir çizgide formüle edildiği aşikârdır. 
Söz konusu çalışmaların ikinci safhası eğitim sistemiyle başlatılmıştır. Çünkü halkın kendi geçmişine dair hafızası ve aidiyet duygusu eğitimin tevkifi ile sınırlandırılmaya çalışılmıştır. Söz konusu olan bakış açısı içinde Ceditçilerden vazgeçen Çarlık, ironik biçimde Kadimçilere destek vererek, yeni kimliğin temeline mahalli dili (lehçe), dini (mezhep), mahalli kültürü ve coğrafi unsurları oturtmuştur. Bu meyanda, çok sayda softanın buluştuğu yeni "Şii" ve "Sünni” medreseler açılmıştır. Çarlık hükümetinin denetimindeki medrese öğrencileri hükümet için işe yarar potansiyel unsurlar olarak değerlendirilmiştir.

Coğrafi sınırlara, yerel geleneklere ve mezhepsel itikatlara istinat edilerek tesis edilen, "Azeri" veya "Azerbaycan Tatarları" denilen yeni kimlik bir kültür formasyonundan başka bir şey değildir. Hatta daha da ileri giderek, "Azeri" ya da "Tatar" kurgusunun kabulü bir yaşam tarzı, ait olma ihtiyacı, toplum nizamı ve tarihsel-kültürel dönüşümlerin gerçekleşmesini amaçlayan tarihsel bağlardan kopuk bir paradoksu ihtiva etmektedir. Swietochowski'ye göre Azerbaycan'da yeni kimliğin oluşum süreci birbiriyle bağlantılı olarak öne çıkan üç unsur üzerinden kategorize edildiği görülmektedir: "Siyasi bağımsızlığı elinden alınmış halkın edebi dil meselesi, geleneksel toplumdan modern topluma geçişe bağlı olarak dönemin sosyal iletişim araçları ve milli-kültürel kimlik arayışı/inşası." (1988: 76).

Azerbaycan toplumunda “Türk” kimliği paradigmasını arka plana iten eksenler, "Azeri" veya "Tatar" kimliğini bir model olarak sunmuştur. Bu istikamette varsayımlar ortaya konulurken şekillendirmeye çalıştıkları tarihsel ve kültürel geleneklerin temel prensipleri bir kurgu niteliği olarak maarifçi görüşlerin ana hattını oluşturmuştur. Bu noktada Zerdabi'nin üzerinde ısrarla durduğu tezine göre, "kültürel kimliğin yapı taşını teşkil eden anadilinin (Türkçe) muhafazası, milli kurtuluş için yegâne kurtuluş yolu olarak görülmüştür." (Swietochowski 1988: 47). Saray'ın tespitine göre, "Batılılaşma/Ruslaştırma adına yapılan kültür emperyalizmi için önce 'Tatar Aydını' kavramı kullanılmak istenildiyse de bu aydınların Türkçülük ve İslamcılık düşüncelerini Türkistan’a yaymak gibi farklı amaçlar doğrultusunda gelişme gösterme ihtimali üzerine, Çarlık bir süre bu politikasından dönmek mecburiyetinde kalmıştır." (1988: 73).

Tarih boyunca farklı medeniyetlerle etkileşim içinde olan Azerbaycan toplumu kendine has davranış ve düşünce yapısından doğan kültürel 
homojenliği, aydınlanma (maarifçilik) algısı kapsamında çeşitlenmiştir. Kimlik tanımlanması gereksinimi, diğer coğrafyalardaki soydaşları ile kurulan ilişkiler modernleşmeyi içine alan boyutlarda ifade edilir hâle gelmiştir. Nitekim kendilerine ait tutarlı bir ideolojiden yoksun olan maarifçi aydınların, kendi ideolojik, milli ve entelektüel "başarısızlıklarının" suçunu kültürel geleneklerde ve İslam dininde araması teşebbüsü, şüphesiz bu kavramlar etrafında bir tanımlanmıştır. Türk-Müslüman toplumunun sahip olduğu kültürel kimliğin ötesinde yeni bir "kimliğin" Çarlık tarafından dayatılması, doğal olarak maarifçiliğe toplumsal seviyede destek ve güç temin etmemiştir. En çok edebiyat alanında kendini gösteren "yeni kimlik" temsilcileri, "natüralist, materyalist, ateist ya da sosyalist araçlardan kendi anlayışlarına uygun bir düşünce kumaşı dokudular ki bunun en ayırıcı yanı geçmişi inkâr, çağa koşmak, ona ayak uydurmak isteğine" (Berkes 2012: 379) ağıllık vermişlerdir.

20. yüzyılın başlarında yayın hayatına başlayan "Füyûzât" dergisinde, Azerbaycan Türklerinin kökleri Anadolu Türklerinin de mensubu olduğu Oğuz boyundan ibaret olduğu görüşü açık dile getirilmiştir (Füyûzat 1907: 24/371). Sahip oldukları kültürel değerler arasındaki farklılıkların dikkate değer olmadığı görüşü maarifçiliğin üçüncü aşamanda belirginlik kazanabilmiştir (Cafer 1963: 178). Çarlık idaresinde "yabancılaştırma" kalıbı içine sıkıştırılan Türklük telakkisi, Füyûzatcıllkla ideolojik boyutunu somutlaştırmıştır. Böylece Azerbaycan'da Türklük, İrancılık ve Rusçuluğa karşı yönelmiş milli bilincin gelişimini, milli kültürün dirilişini ve siyasi idealin gerçekleşmesini amaçlayan siyasi-kültürel hareket gibi ortaya çımıştır (Nasipli 2001: 142).

\section{Sonuç}

19. yüzyılın ikinci yarısından itibaren Azerbaycan toplumunun fikir çerçevesini çizen maarif̧̧ilik akımı modernleşme yolunu takip ettiği aşikârdır. Rusya hegemonyasının mutlak güç olmaya yönelik eğilimleri de modernleşme görünümünden uzak değildir. $\mathrm{Bu}$ bakımdan her iki yaklaşımda Batı medeniyetinin etkisi açı görülmektedir. Her iki yaklaşımı doğru tanımlamak ve çözümlemek için Foucault’nun "bilgiiktidar” denklemine ihtiyaç duyulmaktadır. Bu gelişmeler ışığında kültürel kimlik kavramı, hegemonya için anlamsız bir olguya dönüştürülmüştür. Toplumu dönüştürmek için hegemonyanın itici gücü "maarifçi” aydınların 
çalışmalarında somutluk kazanmıştır. Avrupamerkezci izler somutlaşmış bir hegemonya tasarısı çerçevesinde çizilmiştir. Avrupamerkezci görüş, Rus lisanı, Batı kültürü ve Hristiyan inancı şeklinde tezahür etmiş ve "Ruslaştırma" projesinde somutlaşmıştır.

Gramsci perspektifinden baktığımızda, "entelektüel" ve "hegemonya" kavramları, kültürel kimlik sorunlarının çözümlenmesi noktasında en belirleyici olanıdır. Dikkat çektiğimiz nokta maarifçilik olgusunun Avrupamerkezci stratejilere uygun formüle edilesidir. Çünkü eğitimin seküler yapı içerisinde sunulma ısrarı ve fikirlerin pozitivizm söylemlere istinat edilme çabası yeni kimliğe bürüme ekseninde belirleyici rol oynamaktadır.

Bakü'de petrol sanayisinin gelişmesi hem yeni sınıfsal (burjuva ve işçi) katmanları hem de modern kentleşmeyi meydana çıkardı. Böylece toplumda yeni dinamikleri doğdu. Modernleşme olgusu geri kalmışlıktan kurtulmanın çaresi olarak görüldü. İlerlemenin geleneksel anlayıştan kurtulmakla mümkün olabileceği görüşü tasvip olunmaya başladı. Maarifçilik konseptinin temel felsefesi de bu düşünce üzerine inşa edilmekteydi. A. Bakıhanov, Mirza Kâzım Bey gibi konformist oryantalistler, Ahundov gibi "yakınmacı" rasyonalistleri bir tarafta, Zerdabi gibi kaygılı eğitimciler ise modern değişim heveslisi olarak maarifçi düşünce sistemine sarıldılar. "Avrupamerkezcilik" görüşün temelinde toplumsal sorunların çözümü hakkında fikir birliği içerisinde bulunmaktaydılar. Böylece tarihsel köklere dayanan kültürel ve dini değerler tartışmaların merkezine itildi. Mevcut geri kalmışlı̆ın nedeni olarak bu kavramlar gösterildi. Gelinen son durumun asıl müsebbibi olan hegemonik yönetim maarifçilerin açık siyasi mücadele hedefinden uzak kalmaktaydı.

\section{Kaynaklar}

Abdullayeva, Terane (2014). Azerbaycan Edebi Fikrinde Garp̧̧ıllk Meyilleri. Bakü: Avrupa Yay.

Abou El-Haj, Rıfat Ali (2000). Modern Devletin Doğası: 16. Yüzyzldan 18. Yüzynla Osmanlı İmparatorluğu. Çev. Oktay Özel. Ankara: İmge Kitabevi Yay.

Aça, Mustafa (2004). "Ortak Kimliğin Yeniden İnşası ve Türkiye-Azerbaycan-

Orta Asya Türk Cumhuriyetleri İlişkileri Bağlamında Türklük Bilimi Araştırmalarının Rolü’. Kök Sosyal ve Stratejik Araştırmaları Dergisi 4: 1128.

Açıkkaya, Savaş (2010). "Çarlık Rusyası Hâkimiyetindeki Azerbaycan Türklerinde 
Ulus Bilincinin Gelişmesinin Temel Dinamikleri”. Erciyes Üniversitesi Sosyal Bilimler Dergisi 28: 403-420.

Ahundov, Mirza Fetali (2005). Eserleri. C. 2. Bakü: Şark-Garp Yay.

Akçura, Yusuf (1928). Türk Yılı: 1928. İstanbul: Yeni Matbaa.

Akpınar, Yavuz (1980). Mirza Fethali Ahundzade: Bütün Yönleri İle. Erzurum.

Alimirzayev, Halit (2007). M. F. Ahundov'un İdeal ve Sanat Dünyası. Bakü: Nurlan Yay.

Aliyev, Rahim (2008). Edebiyyat Nezeriyyesi. Bakü: Mütercim Yay.

Bakıhanov, A. Ağa (2005). Seçilmiş Eserleri. Bakı: Avrasya Press Yay.

Barthold, Vasiliy (2004). Rusya ve Avrupa'da Oryantalizm. Çev. Kaya Bayraktar ve Ayşe Meral. İstanbul: Küre Yay.

Baykara, Hüseyin (1966). Azerbaycan'da Yenileşme Hareketleri (XIX). Ankara: TKAE Yay.

Baykara, Hüseyin (1975). Azerbaycan İstiklal Mücadelesi Tarihi. İstanbul: Gençlik Yay.

Berdiaev, Nikolay (2008). Russkaya İdeya. St. Petersburg: Azbuka-Klassika.

Berkes, Niyazi (2012). Türkiye'de Çăgdaşlaşma. İstanbul: YKY.

Bozkurt, Nejat (1988). "Michel Foucault Felsefesinin Bazı Temel Kavramları". Defter 4: 39-50.

Buttigieg, Joseph A. (Ed.). (2012b). Antonio Gramsci: Hapishane Defterleri. Cilt 3. Çev. Barış Baysal. İstanbul: Kalkedon Yay.

Cafer, Mehmet (1963). Azerbaycan Edebiyatında Romantizm. Bakü: Azerneşr.

Caferoğlu, Ahmet (1964). "Azerbaycan'da Maarif Hareketleri”. Türk Kültürü 18.

Caferova, Nabat (2016). Azerbaycan Dilinin Tedrisi Metodikası. Bakü: ADPU. Yay.

Can, Turan (2017). “Türk Dünyasında Kültürel Asimilasyon Politikaları”. https:// www.altayli.net/turk-dunyasinda-kulturel-asimilasyon-politikalari-ii.html (Erişim Tarihi: 15.11.2018)

Carr, H. Edward (1996). Tarih Nedir? Çev. Misket Gizem Gürtürk. İstanbul: İletişim Yay.

Çiğdem, Ahmet (1997). Aydınlanma Düşüncesi. İstanbul: İletişim Yay. http://www. academia.edu/ (Erişim Tarihi 23.02.2017).

Devlet, Nadir (1994), "Çarlık Rusyası ve Sovyetler Birliğinin Türk Tarihine Bakışı”. http://www.academia.edu/ (Erişim Tarihi 23.02.2017).

Elyarlı, Süleyman (1991). Azerbaycan Milli Harekatının İlkin Dönemleri. Ankara: Yeni Forum Yay.

Erkal, Mustafa (1998). Sosyoloji (Toplumbilim). İstanbul: Der Yay.

Erol, Ali (2006). “Türk Kültür ve Fikir Hayatında Ekinçi (1875-1877)”. bilig, Türk Dünyası Sosyal Bilimler Dergisi 54: 53-72.

Foucault, Michel (1999). Bilginin Arkeolojisi. Çev. Veli Urhan. İstanbul. Birey Yay. 
Foucault, Michel (2014). Özne ve İktidar. Çev. Işık Ergüden ve Osman Akınhay. 4. Baskı. İstanbul: Ayrıntı Yay.

Füyûzât Dergisi (1907). Bakü: 24/371.

Gramsci, Antonio (1986). Hapishane Defterleri. Çev. Kenan Somer. İstanbul: Onur Yay.

Guibernau, Montserrat (1997). Milliyetçilik. Çev. Neşe Nur Domaniç. İstanbul: Sarmal Yay.

Gündoğdu, Abdullah (2008). “Türk Aydınlanması, Türk Çağdaşlaşması, Türk Milliyetçiliğì". 21. Yüzyzl Dergisi 5: 37-46.

Hacısalihoğlu, Fuat (2012). Azerbaycan'da Tarihçilik. Doktora Tezi. Ankara: Ankara Üniversitesi.

Hobson, M. John (2015). Batı Medeniyetinin Doğulu Kökenleri. Çev. Esra Ermert. İstanbul: $\quad$ YKY.

Hodgson, G. S. Marshall (2017). Dünya Tarihini Yeniden Düşünmek. Çev. Ahmet Kanlıdere. İstanbul: Vadi Yay.

Horata, Osman (2017). “Türk Dünyası'nın Kültürel Ufukları: Tarihsel Bir Bağlam İçinde Genel Bir Değerlendirme”. bilig, Türk Dünyası Sosyal Bilimler Dergisi 82: $117-131$.

Hüseynov, Haydar (2007). Azerbaycan'da 19. Asir İctimai ve Felsefi Fikir Tarihinden. Bakü: Şark-Garp Yay.

Kasımzade, Feyzulla (1956). XIX Asır Azerbaycan Edebiyatı Tarihi. Bakı: Azerbaycan Devlet Üniversitesi Neşriyatı.

Kastrati, Babashova Z. (2017). ”Azerbaycan Edebiyatının Modernleşmesinde Hasan Bey Zerdabi’nin 'Ekinçi' Gazetesinin Rolü’. Insan ve Toplum Bilimleri Araştırmaları Dergisi 7: 264-276.

Kanlıdere, Ahmet (2012). "Mirza Kâzım Bey”. İslam Ansiklopedisi. C. 30. İstanbul: TDV Yay. 164.

Kızılkaya, Ertuğrul (2013). "Foucault ve Agamben'de Dispozitif Kavramı ve İktisat”. Cumburiyet Üniversitesi İktisadi ve İdari Bilimler Dergisi 14 (2): 19-41.

Kolosov, A. B. (2000). Geopolitiçeskoe Polojenie Rossii: Predstavlenia i realnost. Moskva: Art-Kuryer.

Lacoste, Y. (2014). Coğrafya Her Şeyden Önce Savaş Yapmaya Yarar. Çev. Selim Sezer. İstanbul: Ayrıntı Yay.

Larrain, Jorge (1995). İdeoloji ve Kültürel Kimlik. Çev. Neşe Nur Domaniç. İstanbul: Sarmal Yay.

Mahmudov, Yagub (2005). “Azerbaycan Maarifçiliyi”. Azerbaycan Xalq Cumburiyeti Ensiklopediyası. C. 1. Bakü: Lider Yay. 45-47.

Mardin, Şerif (2013). Yeni Osmanl Dü̧̈̈̈ncesinin Doğuşu. İstanbul: İletişim Yay.

Mardin, Şerif (2015). Türk Modernleşmesi: Bütün Eserleri Makaleler 4. İstanbul: 
İletişim Yay.

Mehmetzade, Mirza Bala (1991). Milli Azerbaycan Hareketi. Ankara: AKD Yay.

Nağıyeva, Nigar (2017). 1990'dan Günümüze Türkiye ve Azerbaycan Edebiyatının Karşılıklı Etkileşimi. İstanbul: Hiperlink Yay.

Nasipli, Nasip (2001). “Azerbaycan'ın Milli Kimlik Sorunu”. www.21yyt.org/assets/uploads/file (Erişim Tarihi 07.03.2017).

Nuriyeva, İrade (2015). Azerbaycan Tarihi. Bakü: Mütercim Yay.

Ortaylı, İlber (2016). Imparatorluğun En Uzun Yüzyılı. İstanbul: Timaş Yay.

Ramazanov, Faruk (Ed.). (2001). Felsefe. Bakü: Azerbaycan Teknik Üniversitesi Neşriyat1.

Raynaud, P. ve Rials, S. (2003). Siyaset Felsefesi Sözlüğ̈̈. Çev. İsmail Yerguz vd. İstanbul: İletişim Yay.

Rzayev, Ağababa (1965). Mirza Kazım Bek. Bakü: Azerneşr.

Said, Edward (2016). Şarkiyatçılık. Çev. Berna Ülner. İstanbul: Metis Yay.

Saray, Mehmet (1988). “Türkler (Dış Türkler)”. İslam Ansiklopedisi. C. 12. İstanbul: MEB Yay.

Swietochowski, Tadeusz (1988). Müslüman Cemaatten Ulusal Kimliğe Rus Azerbaycanı 1905-1920. İstanbul: Bağlam Yay.

Şimşek, Ahmet (2007). “Türkiye'de Tarih Eğitiminin Ulusallı̆̆ı ve Avrupamerkezcilik". Türkiye Sosyal Araştırmalar Dergisi 1: 16-35.

Turner, Bryan S. (2003). Oryantalizm, Postmodernizm ve Globalizm. Çev. İbrahim Kapaklıkaya. İstanbul: Anka Yay.

Ülken, Hilmi Ziya (2013). Türkiye’de Çăğdaş Düşünce Tarihi. İstanbul: Türkiye İş Bankası Yay.

Velihanlı, Naile (2014). “Abbaskulu Ağa Bakıhanov". Halk Gazetesi: 20.06.2014. Bakü.

Velihanov, Nadir (1983). Azerbaycan Maarifçi-Realist Edebiyatı. Bakü: Elm Yay.

Zenkovsky, Serge (2000). Rusya'da Türkçülük ve İslam. Çev. Ali Nejat Ongun. Ankara: Günce Yay. 


\title{
Perception of Cultural Identity in the Early Period of Azerbaijan Enlightenment ${ }^{*}$
}

\section{Ramesh Rzayev**}

\begin{abstract}
In the history of Azerbaijan's political and philosophical ideas enlightenment has, as a paradigm, an important place in national historic literature despite its contradictions and some inconsistencies. The philosophical, scientific and cultural arrangements that Russia has imposed on Azerbaijan since the 19th century have led to the formation of new life. We can say that the activities of A. Bakıkhanov, M. Kazim Bay, M. F. Akhundov and H. Zerdabi who are representatives of the educating-humanist worldview, are based on the assumption of setting a new society's lifestyle. Being a form of expression, modernization realized mostly under the influence of West brought a new quality into the life of thought and national-cultural notion in Azerbaijan and it is possible to see the effect almost in all areas of life. Discrimination and irredentist policy of Tsarist Russia against Azerbaijani people is an obvious reflection of political and ideological parallels on national identity. In the period of modernization the central problem of the national culture and identity has been seen to be composed of subjective approaches of views connected with the world. Categorization of socio-political and philosophical ideas on the basis of modernization discourse that express characteristic features on recognition of identity obviously paved the way for new consciousness to come out.
\end{abstract}

\section{Keywords}

Azerbaijani Enlightenment, hegemony, culture, identity, illumination, discrimination, irredentist.

\footnotetext{
Date of Arrival: 13 February 2018 - Date of Acceptance: 30 January 2019

You can refer to this article as follows:

Rzayev, Rameş (2020). "Erken Dönem Azerbaycan Maarif̧̧iliğinde Kültürel Kimlik Algısı". bilig Journal of Social Sciences of the Turkic World 95: 123-148.

“ PhD Student, Sakarya University, Institute of Social Sciences, Department of History - Sakarya/Turkey ORCID ID: 0000-0001-9699-8116

ramesrza@gmail.com
} 


\title{
Восприятие культурной самобытности в ранний период азербайджанского просвещения*
}

\author{
Рамеш Рзаев **
}

\begin{abstract}
Аннотация
В истории политических и философских идей Азербайджана просвещение как парадигма занимает важное место в отечественной исторической литературе, несмотря на его противоречия и некоторые несоответствия. Философские, научные и культурные меры, которые Россия навязала Азербайджану с XIX века, привели к формированию новой жизни. Можно сказать, что деятельность представителей образовательно-гуманистического мировоззрения А. Бакиханова, А.К. Казембека, М.Ф. Ахундова и Х. Зердаби основана на предположении об установлении нового образа жизни общества. Как форма выражения, модеринизация, осуществленная в основном под влиянием Запада, внесла новое качество в мышление и национальнокультурные представления в Азербайджане, и это влияние можно увидеть практически во всех сферах жизни. Политика дискриминации царской России в отношении азербайджанского народа является очевидным отражением политических и идеологических параллелей в национальной идентичности. В период модернизации центральная проблема национальной культуры и идентичности рассматривалась как состоящая из субъективных подходов во взглядах, связанных с миром. Категоризация социально-политических и философских идей на основе модернизационного дискурса, выражающего характерные черты признания идентичности, очевидно, проложила путь к появлению нового сознания.
\end{abstract}

\section{Ключевые слова}

Азербайджанское просвещение, гегемония, культура, идентичность, освещение, дискриминация, ирредентизм.

\footnotetext{
* Поступило в редакцию: 13 февраля 2018 г. - Принято в номер: 30 января 2019 г. Ссылка на статью:

Rzayev, Rameş (2020). "Erken Dönem Azerbaycan Maarif̧̧iliğinde Kültürel Kimlik Algısı”. bilig - Журнал Гуманитарных Наук Тюркского Мира 95: 123-148.

** Аспирант, Университет Сакарьи, Институт общественных наук, кафедра истории - Сакарья / Турция ORCID ID: 0000-0001-9699-8116 ramesrza@gmail.com
} 